\title{
FACET JOINT DEGENERATION IN PATIENTS WITH LUMBAR DISC HERNIATION AND PROBABLE DETERMINING FACTORS
}

\author{
DEGENERAÇÃO FACETÁRIA EM PACIENTES COM HÉRNIA DE DISCO LOMBAR E PROVÁVEIS \\ FATORES DETERMINANTES
}

\section{DEGENERACIÓN FACETARIA EN PACIENTES CON HERNIA DE DISCO LUMBAR Y PROBABLES FACTORES DETERMINANTES}

\author{
Rodrigo Arnold Tisot, ${ }^{1,23}$ Juliano da Silveira Vielira, ${ }^{3}$ Diego da Silva Collares, ${ }^{2,3}$ Darby Lira Tisatto, ${ }^{2,3}$ Augusto Pasinl, ${ }^{1}$ Brenda Gobetil, ${ }^{1}$ Eduardo Coronel, \\ Eduardo Scharnovski, ${ }^{1}$ Malara Agostini, ${ }^{1}$ Mateus Borin, ${ }^{1}$ Pedro Ruschel, ${ }^{1}$ Walter Iserhard, ${ }^{1}$ Luiza Rech Kohler ${ }^{1}$ \\ 1. Universidade de Passo Fundo - UPF, Faculdade de Medicina, Passo Fundo, RS, Brazil. \\ 2. Hospital Ortopédico de Passo Fundo - HO, Spine Surgery Service, Passo Fundo, RS, Brazil. \\ 3. Hospital de Clínicas de Passo Fundo - HC, Passo Fundo, RS, Brazil.
}

\begin{abstract}
Objective: To evaluate facet joint degeneration following surgical treatment in patients with lumbar disc herniation, seeking to correlate it with possible determining factors. Methods: Cross-sectional observational study, which analyzed medical records, radiographs and magnetic resonance images of 287 patients with lumbar disc herniation treated surgically at the Spine Surgery Service of the Hospital Ortopédico de Passo Fundo. Information about age and sex was collected. In the imaging exams, the following variables were evaluated: facet joint angulation and its tropism, measured by the Karacan method, sacral slope and lumbar lordosis, measured by the Cobb method, arthrosis of the interfacetary joints, measured by the Weishaupt classification, and intervertebral disc degeneration, measured by the Pfirrmann classification. Results: A statistically significant relationship was observed between facet joint degeneration and age $(p=0.002)$, and also between facet joint degeneration and sacral slope $(p=0.038)$. No correlation was found between facet joint degeneration and lumbar lordosis $(p=0.934)$. It was found that the most degenerated facet joints were those that had the greatest facet joint asymmetry (tropism). However, the mean degree of facet tropism did not increase homogeneously with the progression of the joint degeneration score $(p=0.380)$. Conclusion: It was verified that there are, in fact, a multiplicity of factors related to the degree of facet joint degeneration in the low lumbar spine. Additional studies, correlated with the asymmetry of the facet joints, would be important to elucidate better preventive management of this degeneration, aiming to avert secondary low back pain and sciatica with advancing age. Level of evidence II; Retrospective study.
\end{abstract}

Keywords: Intervertebral Disc Degeneration; Low Back Pain; Hernia; Lumbosacral Region.

\section{RESUMO}

Objetivo: Avaliar a degeneração facetária em pacientes com hérnia de disco lombar tratados cirurgicamente, procurando correlacioná-la com possiveis fatores determinantes. Métodos: Estudo observacional do tipo transversal, que analisou prontuários, radiografias e ressonâncias magnéticas de 287 pacientes com hérnia de disco lombar, tratados cirurgicamente no Serviço de Cirurgia da Coluna do Hospital Ortopédico de Passo Fundo. Foram coletadas informações sobre idade e sexo. Nos exames de imagem, foram avaliadas as seguintes variáveis: angulação facetária e seu tropismo, mensurada pelo método de Karacan, inclinação sacral e lordose lombar, medidas pelo método de Cobb, artrose das articulações interfacetárias, pela classificação de Weishaupt e degeneração do disco intervertebral, pela classificação de Pfirrmann. Resultados: Foi verificada relação estatisticamente significativa entre degeneração facetária e idade $(p=0,002)$, assim como entre degeneração facetária e inclinação sacral $(p=0,038)$. Não foi encontrada correlação entre degeneração facetária e lordose lombar ( $p$ $=0,934)$. Constatou-se que as articulações facetárias mais degeneradas eram as que tinham maior assimetria facetária (tropismo). Porém, a média do grau de tropismo facetário não aumentou de forma homogênea com a progressão do escore de degeneração da articulação $(p=0,380)$. Conclusões: Verificou-se que há, de fato, uma multiplicidade de fatores relacionados com o grau de degeneração facetária da coluna lombar baixa. Estudos adicionais correlacionados com a assimetria das referidas articulações seriam importantes para elucidarmos uma conduta preventiva melhor para a referida degeneração, objetivando evitar lombalgia e ciatalgia secundárias à medida que a idade avança. Nível de evidência II; Estudo retrospectivo.

Descritores: Degeneração do Disco Intervertebral; Dor Lombar; Hérnia; Região Lombossacral.

\section{RESUMEN}

Objetivo: Evaluar la degeneración facetaria en pacientes con hernia de disco lumbar tratados quirúrgicamente, buscando correlacionarla con posibles factores determinantes. Métodos: Estudio observacional del tipo transversal, que analizó historiales, radiografías y resonancias magnéticas de 287 pacientes con hernia de disco lumbar, tratados quirúrgicamente en el Servicio de Cirugía de la Columna del Hospital Ortopédico de Passo Fundo. Fueron colectadas informaciones sobre edad y sexo. En los exámenes de imagen, se evaluaron las siguientes variables: angulación facetaria y su tropismo, medida por el método de Karacan, inclinación sacral y lordosis lumbar, medidas por el método 
de Cobb, artrosis de las articulaciones interfacetarias, por la clasificación de Weishaupt, y degeneración del disco intervertebral, por medio de la clasificación de Pfirrmann. Resultados: Se verificó relación estadísticamente significativa entre degeneración facetaria y edad ( $p=$ 0,002), así como entre degeneración facetaria e inclinación sacral $(p=0,038)$. No se encontró correlación entre degeneración facetaria y lordosis lumbar $(p=0,934)$. Se constató que las articulaciones facetarias más degeneradas eran las que tenían mayor asimetría facetaria (tropismo). Sin embargo, el promedio del grado de tropismo facetario no aumentó de forma homogénea con la progresión del score de degeneración de la articulación ( $p=0,380)$. Conclusiones: Se verificó que hay, de hecho, una multiplicidad de factores relacionados con el grado de degeneración facetaria de la columna lumbar baja. Estudios adicionales correlacionados con la asimetría de las referidas articulaciones serían importantes para que elucidemos una mejor conducta preventiva para la referida degeneración, con el objetivo de evitar lumbalgia e ciatalgia secundarias, a medida que la edad avanza. Nivel de evidencia II; Estudio retrospectivo.

Descriptores: Degeneración del Disco Intervertebral; Dolor de la Región Lumbar; Hernia; Región Lumbosacra.

\section{INTRODUCTION}

Low back pain is a frequent symptom, affecting $80 \%$ of adults at some time during their lives. It is one of the ten main causes for consultations and each year is the reason that 5 to $10 \%$ of workers are absent from their jobs for more than seven days. ${ }^{1}$ Disc herniation is the degenerative disease that leads to the highest number of spinal surgeries in adults. ${ }^{2}$ This lesion can occur in any age group, but is most prevalent between 40 and 50 years of age. It is estimated that 2 to $3 \%$ of the general population may be affected, or approximately $5 \%$ in men and $2.5 \%$ in women. ${ }^{3}$

The spine is the main body support axis for the trunk and appendicular limbs, resisting the forces of compression, anteriorly, and tension, posteriorly. While this structure, formed by a complex group of osseous and discoligamentary structures, is axially very resistant, it also enables important mobility for the execution of multiple movements of flexion-extension, lateralization, and rotation. ${ }^{4,5}$ Each vertebral segment contains a triarticular complex, composed of the intervertebral disc and the paired, bilateral facet joints. While the intervertebral disc allows spinal movement, although limited, in all planes, the facet joints are naturally limited by their orientations, geometric positions, and capsules. ${ }^{6}$ Thus, there is a mechanism to control the axial rotation of the lumbar spine, which prevents the occurrence of vertebral shear. ${ }^{7}$ It should be noted that there is a natural asymmetry between the orientation of the facet joints, called facet joint tropism. ${ }^{8}$ Sacral slope and lumbar lordosis are also factors that vary from individual to individual and cause biomechanical changes in the load axis of the lumbar spine. ${ }^{9}$

Biomechanical changes below the lumbosacral spine can accelerate the aging of that region and in many individuals early degenerative changes cause chronic low back pain, often incapacitating and difficult to control. ${ }^{1,6,10}$ In patients with lumbar disc herniation whose main complaint is radicular, i.e., sciatalgia, low back pain may be associated with the early degenerative lumbosacral process that occurs in some individuals. After a surgical discectomy procedure, which aims to improve sciatica, the patient sometimes expresses frustration with the treatment because of persistent residual low back pain, which is actually caused by the local degenerative process and load distribution over the region. ${ }^{11}$

Thus, the objective of the present study is to evaluate facet joint degeneration in patients with surgically-treated lumbar disc herniation, seeking to correlate it with possible determining factors, such as age, facet joint tropism, intervertebral disc degeneration, sacral slope, and lumbar lordosis.

\section{METHODS}

This is a cross-sectional observational study that analyzed the medical records of patients with surgically-treated lumbar disc herniation. All the patients were treated at the Spine Surgery Service of the Hospital Ortopédico de Passo Fundo (RS), which also operates at the Hospital de Clínicas de Passo Fundo (RS).

The authors of this study signed a data use agreement, committing to data anonymity. The research project was approved by the Institutional Review Board of the Universidade de Passo Fundo (IRB/ UPF), after having been forwarded via Plataforma Brasil (protocol number 2.929.767).
The study was conducted with data collected from the medical records of 287 patients diagnosed with lumbar disc herniation who underwent discectomy surgery during the period from 2002 to 2017.

As inclusion criteria, patients were selected who had undergone surgery for lumbar disc herniation and whose medical records had lumbosacral radiographs in anteroposterior and lateral views and magnetic resonance of the lumbosacral spine with axial cuts.

Patients with disc herniation at more than one level, herniation with bilateral radicular involvement, imaging examinations not suitable for measuring and classification, spondylolisthesis, or with spinal deviations of more than 10 degrees in the coronal plane were excluded from the study.

Information about sex and age was collected from the medical records. The following imaging examination variables were evaluated: location and level of the herniation according to Wiltse, ${ }^{12}$ facet joint angulation and tropism measured by the Karacan et al. method, ${ }^{13}$ sacral slope and lumbar lordosis measured by the Cobb method using the Cobbmeter ${ }^{\circledR}$ application, facet joint arthrosis according to the Weishaupt classification, ${ }^{14}$ and intervertebral disc degeneration according to the Pfirrmann classification. ${ }^{15}$

The descriptive quantitative data were expressed as means and standard deviations or, in case of asymmetrical distribution, as medians and interquartile intervals (25th percentile - 75th percentile), and the categorical data as relative frequencies and percentages. A normality test (Kolmogorov-Smirnov) was applied to the quantitative variables and the need to use non-parametric tests was determined. Thus, the Mann-Whitney U-test was used for comparison and the Spearman rank test was used for the correlations. The chisquare test was used to compare the proportions. These analyses were performed using the Statistical Package for the Social Sciences (SPSS) version 18.0 software (SPSS Inc., Chicago, IL, USA). The $p$-value indicated as statistically significant was $p<0.05$.

\section{RESULTS}

The results were obtained according to: (a) demographic data; (b) the correlation between facet joint degeneration and age; (c) the correlation between facet joint degeneration and facet joint tropism; (d) the correlation between facet joint degeneration and disc degeneration; (e) the correlation between facet joint degeneration and sacral slope; and (f) the correlation between facet joint degeneration and lumbar lordosis.

\section{a. Demographic data}

Regarding the sex of the patients, 144 were male (50.2\%) and 143 were female (49.8\%), The patients ranged in age from 19 to 84 years of age, with a mean age of 46.3 years.

As regards the disc space where the herniation occurred, the predominant involvement was in L5-S1 in 136 patients (47.4\%) and in L4-L5 in 120 patients (41.6\%).

In relation to the side where the disc herniation occurred, 146 patients were affected on the left (50.9\%) and 141 on the right (49.1\%).

When evaluating the locations where the lumbar intervertebral disc herniations occurred, it was found to be central-lateral in 223 patients $(77.7 \%)$, foraminal in 24 patients $(8.4 \%)$, central in 29 patients $(10.1 \%)$, and extra-foraminal in 11 patients $(3.8 \%)$. 
According to the Weishaupt classification, ${ }^{14}$ used to analyze facet joint degeneration, 42 patients were evaluated as grade 0 (14.6\%), 124 as grade 1 (43.2\%), 88 as grade $2(30.7 \%)$, and 33 as grade $3(11.5 \%)$. (Table 1 )

According to the Pfirrmann classification ${ }^{15}$ used to analyze disc degeneration, 6 patients were evaluated as grade 1 (2.1\%), 43 as grade $2(15.0 \%), 136$ as grade $3(47.4 \%), 85$ as grade $4(29.6 \%)$, and 17 as grade 5 (5.9\%). (Table 2)

\section{b. Correlation between facet joint degeneration and age}

The evaluation of the correlation between facet joint degeneration and age showed statistical significance $(p=0.002)$, i.e., as age increases, so does the Weishaupt grade.

\section{c. Correlation between facet joint degeneration and facet joint tropism}

No statistically significant results were found $(p=0.380)$ in the evaluation of the correlation between facet joint degeneration and facet joint tropism. It was observed, therefore, that the mean degree of facet joint tropism did not increase homogeneously with the progression of the joint degeneration score. However, it was found that the most degenerated facet joints (Weishaupt grade 3) were those with the greatest facet joint tropism (facet joint asymmetry). (Table 3)

\section{d. Correlation between facet joint degeneration and disc degeneration}

A statistically significant correlation was found in the evaluation of the correlation between facet joint degeneration and disc degeneration $(p=0.001)$. It was confirmed, therefore, that the greater the facet joint degeneration, the more the intervertebral disc was also degenerated.

\section{e. Correlation between facet joint degeneration and sacral slope}

A weak statistical correlation was observed in the evaluation of the correlation between facet joint degeneration and sacral slope $(p=0.038)$. Therefore, the greater the sacral slope, the more degenerated the facet joint tended to be.

\section{f. Correlation between facet joint degeneration and lumbar lordosis}

Table 1. Grade of facet joint generation.

\begin{tabular}{c|c}
\hline Weishaupt & Number of patients (\%) \\
\hline 0 & $42(14.6)$ \\
\hline 1 & $124(43.2)$ \\
\hline 2 & $88(30.7)$ \\
\hline 3 & $33(11.5)$ \\
\hline Total & $287(100)$ \\
\hline
\end{tabular}

Table 2. Grade of disc degeneration.

\begin{tabular}{c|c}
\hline Pfirrmann & Number of patients (\%) \\
\hline 1 & $6(2.1)$ \\
\hline 2 & $43(15)$ \\
\hline 3 & $136(47.4)$ \\
\hline 4 & $85(29.6)$ \\
\hline 5 & $17(5.9)$ \\
\hline Total & $287(100)$ \\
\hline
\end{tabular}

Table 3. Relationship between facet joint degeneration and the mean degrees of facet joint tropism.

\begin{tabular}{c|c}
\hline Weishaupt & Mean degrees of facet joint tropism \\
\hline 0 & 7.88 \\
\hline 1 & 6.84 \\
\hline 2 & 6.68 \\
\hline 3 & 8.12 \\
\hline Overall mean & 7.09 \\
\hline
\end{tabular}

No statistically relevant results were found in the evaluation of the correlation between facet joint degeneration and lumbar lordosis $(p=0.934)$. It was verified, therefore, that there was no significantly greater facet joint degeneration in spines with more pronounced lumbar lordosis.

\section{DISCUSSION}

Low back pain is the most common painful syndrome and generates huge expenses for society. Arthrosis of the intervertebral disc and facet joints is a prevalent cause of pain with advancing age. ${ }^{16-18}$ Facet joint arthrosis, which often causes low back pain when the individual experiences axial load or movements of extension over the trunk, may occur earlier in some individuals than in others. The precocity of facet joint degeneration may have a genetic origin but may also be associated with anatomical and biomechanical characteristics or with external factors. 5,18,19

With regard to the age of the patients, our study found that degenerative changes tend to progress with age $(p=0.002)$, a fact well-documented in world literature. ${ }^{18,19}$

The importance of angulation and facet asymmetry, confirmed by facet joint tropism, in relation to pathologies of the lumbar spine,

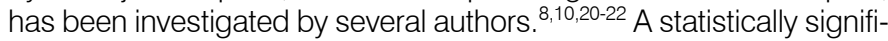
cant relationship between the side of the tropism and the side where the lumbar disc herniation occurs, as described by Tisot et al., ${ }^{8}$ was apparent. The association between the degree of facet joint angulation and the appearance of degenerative spondylolisthesis, as described by Samartzis ${ }^{23}$ and Chotiyarnwong et al., ${ }^{22}$ was also found to be statistically significant. In the present study, it was also observed that the most degenerated joints, those classified as Weishaupt grade $3,{ }^{14}$ were those where the highest mean tropism was encountered (8.12). Although the relationship between tropism and facet joint arthrosis was non-existent ( $p=0.380$ ), we believe that this occurred as a result of evaluating different age groups simultaneously. Because only patients with disc herniation were evaluated, many of whom were young and, although with greater facet joint tropism, did not yet have significant disc or facet joint degeneration, we believe that the relationship could be different if only patients from an older age group were evaluated. We think that a probable axial shearing movement toward the most coronalized facet joint (direction of the greatest tropism) may initially cause a complaint of greater lumbar pain and be a factor that influences the earlier appearance of disc and facet joint degeneration. However, further studies on the topic should be conducted so that these statements can be better defined.

As a result of the greater, more accentuated facet tropism (asymmetry of the facet joints), the lumbar degenerative cascade, originally described as the initial degeneration of the intervertebral disc followed by the degeneration of the interfacetary joints, could alter the order of articular degeneration, starting in the articular facets and subsequently triggering the degeneration of the intervertebral disc. ${ }^{10}$ In the present study, only the correlation between facet joint and disc degeneration was evaluated, which was shown to be statistically significant $(p \leq 0.001)$. This intimate relationship, however, had already been described in the literature by Battié ${ }^{5}$ and Benoist et al. ${ }^{18}$

Regarding the contribution of the sagittal spinal parameters to the origin or worsening of facet joint degeneration, Lv et al. ${ }^{24}$ describe the statistically significant correlation $(p<0.001)$ between the sacral slope and the onset of facet joint degeneration. In the present study, it was also found that the sacral slope is a relevant factor in the genesis or worsening of facet joint degeneration ( $p=0.038)$. Nevertheless, in the evaluation of the correlation between facet joint degeneration and lumbar lordosis, no statistically significant results were found $(p=0.934)$. This could be explained by the fact that an elevated sacral slope will not always be accompanied by accentuated lordosis.

\section{CONCLUSION}

According to the results of this study, we understand that there is, in fact, a multiplicity of factors related to the degree of facet joint degeneration. We found statistically significant relationships between 
facet joint degeneration and age, local disc degeneration, and sacral slope, but not between facet joint degeneration and lumbar lordosis.

Regarding the asymmetry of the facet joints (tropism), it was found that the most degenerated facet joints (Weishaupt grade 3) were those with the greatest facet joint tropism. However, the mean degree of facet joint tropism did not increase homogeneously with the progression of the joint degeneration score. Additional studies correlated with the asymmetry of these joints would be important for us to shed light on better preventive management of this degeneration with the goal of avoiding secondary lower back pain and sciatalgia as age progresses.

All authors declare no potential conflict of interest related to this article.

CONTRIBUTION OF THE AUTHORS: Each author made significant individual contributions to this manuscript. RAT was the creator and advisor present in all phases of the study, as well as the advocate for the study patients. JSV and DSC contributed to the correction of the article; DLT performed data collection from the medical records and participated in the preparation of the results and development of the text. AP, BG, EC, ES, MA, MB, PR, WI, LRK reviewed the literature and participated actively in the preparation of the statistics and the text.

\section{REFERENCES}

1. Henrotin YE, Cedraschi C, Duplan B, Bazin T, Duquesnoy B. Information and low back pain management: a systematic review. Spine (Phila Pa 1976). 2006;31(11):326-34.

2. Weber H. Lumbar disc herniation. A controlled, prospective study with ten years of observation. Spine (Phila Pa 1976). 1983;8(2):131-40

3. Vialle LR, Vialle EN, Henao JES, Giraldo G. Lumbar disc herniation. Rev Bras Ortop. 2010;45(1):17-22

4. Videman T, Leppavuori J, Kaprio J, Battié MC, Gibbons LE, Peltonen L, et al. Intragenic polymorphisms of the vitamin $\mathrm{D}$ receptor gene associated with intervertebral disc degeneration. Spine (Phila Pa 1976). 1998;23(23):2477-85.

5. Battié MC, Videman T, Parent E. Lumbar disc degeneration: epidemiology and genetic influences. Spine (Phila Pa 1976). 2004;29(23):2679-90.

6. Varlotta GP, Lefkowitz TR, Schweitzer M, Errico TJ, Spivak J, Bendo JA, et al. The Lumbar Facet Joint: a review of current knowledge: part 1: anatomy, biomechanics, and grading. Skeletal Radiol. 2011;40(1):13-23.

7. Nunes FTB, Conforti-Froes NDT, Negrelli WF, Souza DRS. Genectic and enviromental factors involved on intervertebral disc degeneration. Acta Ortop Bras. 2007:15(1):09-13.

8. Tisot RA, Vieira JS, Collares DS, Stumm LD, Fontana MF, Pasini A, et.al. Influence of facet tropism on the location of lumbar disc herniation. Coluna/Columna. $2018 ; 17(1): 23-6$

9. Jentzch T, Geiger J, Zimmermann SM, Slankamenac K, Nguyen-Kim TD, Werner CM. Lumbar facet joint arthritis is associated with more coronal orientation of the facet joints at the upper lumbar spine. Radiol Res Pract. 2013;2013:693971.

10. Costa AB, Mattar T, Appolonio PR, Yoshino C, Yonezaki AM, Rodrigues LMR. Associação entre tropismo facetário e doença degenerativa de disco lombar. Coluna/Columna. 2013:12(2):133-7.

11. Atlas SJ, Chang Y, Kamman E, Keller RB, Deyo RA, Singer DE. Long-term disability and return to work among patients who have a herniated lumbar disc: the effect of disability compensation. J Bone Joint Surg Am. 2000;82(1):4-15

12. Wiltse $L L$, Berger PE, McCulloch JA. A system for reporting the size and location of lesions in the spine. Spine (Phila Pa 1976). 1997;22(13):1534-7.

13. Karacan I, Aydin T, Sahin Z, Cidem M, Koyuncu H, Aktas I, et al. Facet angles in lum- bar disc herniation: their relation to anthropometric features. Spine (Phila Pa 1976) 2004:29(10):1132-6.

14. Weishaupt D, Zanetti M, Boos N, Hodler J. MR imaging and CT in osteoarthritis of the lumbar facet joints. Skeletal Radiol. 1999;28(4):215-9.

15. Pfirrmann CW, Metzdorf A, Zanetti M, Hodler J, Boos N. Magnetic resonance classification of lumbar intervertebral disc degeneration. Spine (Phila Pa 1976). 2001;26(17):1873-8.

16. Fujiwara A, Tamai K, An HS, Kurihashi T, Lim TH, Yoshida H, et al. The relationship between disc degeneration, facet joint osteoarthritis, and stability of the degenerative lumbar spine. J Spinal Disor. 2000;13(5):444-50

17. Boden SD, Riew KD, Yamaguchi K, Branch TP, Schellinger D, Wiesel SW. Orientation of the lumbar facet joints: association with degenerative disc disease. J Bone Joint Surg Am 1996:78(3):403-11

18. Benoist M. Natural history of the aging spine. Eur Spine J. 2003;12(Suppl 2):S86-9.

19. Yong-Hing K, Kirkaldy-Willis WH. The pathophysiology of degenerative disease of the lumbar spine. Orthop Clin North Am. 1983:14(3):491-504.

20. Lee DY, Ahn Y, Lee SH. The influence of facet tropism on herniation of the lumbar disc in adolescents and adults. J Bone Joint Surg Br. 2006;88(4):520-3.

21. Noren R, Trafimow J, Andersson GB, Huckman MS. The Role of facet joint tropism and facet angle in disc degeneration. Spine (Phila Pa 1976). 1991;16(5):530-2

22. Pichaisak W, Chotiyarnwong C, Chotiyarnwong P. Facet joint orientation and tropism in lumbar degenerative disc disease and spondylolisthesis. J Med Assoc Thai. 2015;98(4):373-9.

23. Samartzis D, Cheung JP, Rajasekaran S, Kawaguchi Y, Acharya S, Kawakami M et al. Critical Values of Facet Joint Angulation and Tropism in the Development of Lumbar Degenerative Spondylolisthesis: An International, Large-Scale Multicenter Study by the AOSpine Asia Pacific Research Collaboration Consortium. Global Spine J. 2016;6(5):414-21.

24. Lv X, Liu Y, Zhou S, Wang Q, Gu H, Fu X, et al. Correlations between the feature of sagittal spinopelvic alignment and facet joint degeneration: a retrospective study. BMC Musculoskelet Disord. 2016;17(1):341. 